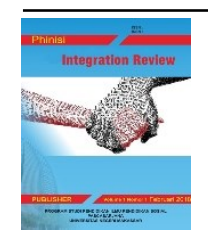

Phinisi Integration Review

Vol. 4, No.2, Juni 2021 Hal 301-308

Website: http://ojs.unm.ac.id/pir

p-ISSN: 2614-2325 dan e-ISSN: 2614-2317

DOI: https://doi.org/10.26858/pir.v4i2.22095

\title{
Adaptasi Penyandang Disabilitas di Lingkungan Masyarakat (Studi Kasus Penyandang Disabilitas Netra Pertuni Kota Makassar)
}

\author{
Arwina Fadhilah ${ }^{1}$,Heri Tahir ${ }^{2}$, Darman Manda ${ }^{3}$ \\ ${ }^{123}$ Pendidikan Sosiologi, Universitas Negeri Makassar, Indonesia \\ ${ }^{1}$ Email: arwinafadhilah23@gmail.com
}

\begin{abstract}
Abstrak. Penelitian ini bertujuan untuk mengetahui: (i) Proses sosialisasi yang dialami disabilitas netra pertuni (ii) Bentuk-bentuk adaptasi penyandang disabilitas netra di lingkungan masyarakat (iii) Faktor-faktor apa saja yang mempengaruhi adaptasi penyandang disabilitas netra di lingkungan masyarakat Penelitian ini menggunakan pendekatan deskriptif kualitatif dengan teknik purposive sampling sebanyak 9 informan. Teknik pengumpulan data menggunakan observasi, wawancara, dan dokumentasi. Teknik analisis data menggunakan tiga tahap yaitu; Reduksi data, penyajian data, dan penarikan kesimpulan. Hasil penelitian: (i) Penyandang disabilitas netra dalam proses sosialisasi yang dialami terdapat sikap, nilai, norma, dan perilaku esensial yang dapat diterapkan di kehidupannya agar mampu untuk beradaptasi dan berpartisipasi secara efektif dalam masyarakat, (ii) Bentuk adaptasi penyandang disabilitas netra melahirkan konformitas yang merupakan usaha penyesuaian diri penyandang disabilitas netra dengan mengikuti cara yang berlaku dalam masyarakat, serta pengasingan diri sebagai alternatif di awalawal penyandang disabilitas netra tidak mampu menerima keadaan diri, (iii) Adapun faktor-faktor yang mempengaruhi adaptasi penyandang disabilitas yaitu faktor pendorong adanya kebutuhan fisiologis, rasa aman, rasa kasih sayang, kebutuhan akan penghargaan dan aktualisasi diri. Adapun faktor penghambat yaitu stigma, dimana masyarakat dalam hal ini masih memberi stigma negatif terhadap keberadaan penyandang disabilitas netra.

Kata Kunci: adaptasi, penyandang disabilitas netra, di lingkungan masyarakat.
\end{abstract}

\begin{abstract}
The study aims to discover: (i) the socialization process experienced by visual impairments disabilities of Pertuni, (ii) the forms of adaptation visual impairments disabilities in the community, and (iii) the factors which influence the adaptation of visual impairments disabilities in the community. This study employed a qualitative descriptive approach with purposive sampling technique with 9 informants. Data collection techniques employed observation, interview, and documentation. The data analysis technique used three stages, namely data reduction, data presentation, and conclusion drawing. Based on the results of the study: (i) the visual impairments disabilities in the socialization process are essential attitudes, values, norms, and behaviors that can be applied in their lives to be able to adapt and participate effectively in society, (ii) the form of adaptation of visual impairments disabilities produces conformity which is an effort to adapt to visual impairments disabilities by following the prevailing methods in society, and self-isolation as an alternative at the beginning when visual impairment disabilities are unable to accept their condition (self isolation), and (iii) the factors that influence the adaptation of visual impairments disabilities are the reinforcement factors for the needs of physiology, sense of security, compassion, the needs for appraisal, and self-actualization. The inhibiting factor is a stigma, where the community still gives a negative stigma to the existence of visual impairments disabilities persons.
\end{abstract}

Keywords: adaptation, visually impaired persons, in the community. 


\section{PENDAHULUAN}

Pada dasarnya setiap individu menginginkan bisa hidup secara normal dengan fungsi organ tubuh yang utuh tanpa kekurangan satu pun dari bagian tubuhnya. Dengan demikian, segala aktivitas dalam kehidupan yang dijalani tidak mengalami hambatan. Akan tetapi situasi akan berbeda apabila seseorang kehilangan salah satu fungsi organ tubuhnya diakibatkan karena kecelakaan ataupun bawaan sejak lahir. Hal inilah yang disebutkan pada penyandang disabilitas. Menjadi seorang disabilitas bukanlah suatu hal yang mudah bagi orang-orang yang mengalaminya. Penyandang disabilitas adalah setiap orang yang mengalami keterbatasan fisik, intelektual, mental dan sensorik dalam jangka waktu yang lama dalam berinteraksi dengan lingkungan dapat mengalami hambatan dan kesulitan untuk berpastisipasi secara penuh dengan warga negara lainnya berdasarkan kesamaan hak.

Undang-undang nomor 8 tahun 2016 membagi ragam disabilitas antara lain penyandang disabilitas fisik, penyandang disabilitas intelektual, penyandang disabilitas mental, dan disabilitas sensorik. Peneliti memfokuskan pada disabilitas sensorik yakni disabilitas netra (kelainan pada indera penglihatan). Disabilitas netra atau tunanetra adalah individu yang memiliki hambatan pada penglihatannya, dan dapat diklasifikan ke dalam dua golongan, yaitu buta total (totally blind) dan kemampuan melihat mata rendah (low vision). Indera penglihatan merupakan salah satu indera yang sangat penting bagi individu dalam menjalankan proses adaptasi di lingkungan sekitarnya, dikarenakan indera penglihatan mempunyai fungsi untuk melihat, seperti untuk melihat suatu benda, mengenali orang dari wajah, membaca, berkendara, dan kegiatankegiatan lainnya. Akan tetapi, sebaliknya jika indera penglihatan terganggu tentu akan berdampak terhadap aktivitas seseorang dalam kesehariannya.

Di Kota Makassar terdapat beberapa perkumpulan yang peduli dengan keadaan orang-orang berkebutuhan khusus dan salah satunya adalah Pertuni (Persatuan Tunanetra Indonesia) yang merupakan organisasi nasional dan memiliki tujuan mewujudkan keadaan yang kondusif bagi tunanetra untuk menjalankan kehidupannya sebagai individu dan warga negara yang cerdas, mandiri, dan produktif tanpa diskriminasi dalam segenap aspek kehidupan dan penghidupan. Sebagian besar individu yang mengalami disabilitas pada penglihatannya tergabung dalam organisasi Pertuni. Penyandang disabilitas mempunyai keterbatasan yang membuat mereka mengalami kesulitan beradaptasi, Maka perlu adanya bimbingan beragam kebutuhan khusus agar dapat beradaptasi di lingkungan sosialnya. Proses sosialisasi mengenai kemandirian merupakan suatu sikap individu yang dimana individu akan terus belajar untuk bersikap mandiri dalam mengahadapi berbagai situasi di lingkungan, sehingga pada akhirnya individu akan berpikir dan bertindak sendiri.

Melihat beragam kemampuan yang dimiliki disabilitas netra, menarik untuk dilakukan penelitian tentang adaptasi disabilitas netra di lingkungan masyarakat. Penyandang disabilitas tunanetra merupakan orang berkebutuhan khusus sehingga memerlukan bantuan orang lain dalam kehidupan sehariharinya, akan tetapi mereka juga dapat melakukan kegiatan sendiri yang biasanya dilakukan oleh orang-orang non disabilitas walau tidak semua kegiatan itu dapat dilakukan sendiri. Dengan kata lain disabilitas netra dapat hidup mandiri tanpa merepotkan orang lain. Berdasarkan latar belakang di atas, maka masalah yang akan di kaji adalah adaptasi penyandang disabilitas di lingkungan masyarakat (studi kasus penyandang disabilitas netra pertuni kota Makassar).

\section{TINJAUAN PUSTAKA}

\section{A. Adaptasi}

Adaptasi (Penyesuaian diri) merupakan suatu proses yang mencakup respon mental dan tingkah laku individu, sehingga tercapai keselarasan dan keharmonisan antara diri sendiri dengan lingkungannya (Agustiani, 2009: 146). Penyesuaian diri merupakan suatu proses dalam beradaptasi terhadap lingkungan. Penyesuaian ini mengubah diri individu sesuai dengan keadaan lingkungan, Mengenai aspek penyesuaian diri sebagaimana pendapat Fromm 
dan Gilmore dalam (Desmita, 2009:195) bahwa penyesuaian diri yang sehat adalah apabila individu memiliki empat aspek berikut:

1. Kematangan emosional, dalam kematangan emosional individu yang dapat menyesuaikan diri manakala memiliki kehidupan emosional yang mantap, dapat menyatakan emosinya dengan asertif serta sikap positif dalam menyatakan ekspresi diri.

2. Kematangan sosial, adalah kemampuan individu yang melibatkan dirinya dalam komunitas sosial dimana dia berada, kesediaan dalam bekerja sama, dan sikap toleransi.

3. Kematangan intelektual, ialah individu yang memiliki kematangan intelektual akan lebih mudah menyesuaikan diri dengan lingkungan disekitarnya karena individu tersebut memiliki wawasan tentang konsep diri, dan kepercayaan diri yang memungkinkan individu tersebut dapat melakukan komunikasi interpersonal dalam lingkungan sosialnya.

4. Tanggung jawab personal, merupakan tanda penyesuaian diri yang baik manakala individu itu dapat menyusun rencana kerja dalam kehidupannya, dan menyelesaikannya dengan baik.

Dalam beradaptasi seseorang perlu mendapat sosialisasi agar dapat beradaptasi dengan baik di lingkungan sekitarnya. Sosialisasi merupakan suatu langkah awal dalam beradaptasi. Sosialisasi adalah suatu proses atau transmisi pengetahuan, sikap, nilai, norma, dan perilaku esensial yang bertujuan agar mampu digunakan untuk berpartisipasi efektif dalam masyarakat (Damsar, 2011). Sosialisasi merupakan proses belajar bagi seseorang atau sekelompok orang selama hidupnya untuk mengenali pola-pola hidup, nilai-nilai dan norma sosial agar dapat berkembang menjadi pribadi yang bisa diterima oleh kelompoknya. Melalui proses sosialisasi seseorang atau sekelompok orang menjadi mengetahui dan memahami bagaimana individu harus bertingkah laku di lingkungan masyarakatnya, mengetahui dan menjalankan hak-hak dan kewajibannya berdasarkan peranan-peranan yang dimilikinya.

Orang-orang disabilitas bukan hanya sekedar dapat berpartisipasi dilingkungan sosial seperti manusia non disabilitas pada umumnya, tetapi juga meningkatkan jaringan sosial, keterampilan, kemandirian, dan menjalankan berbagai peran sosial. Menurut Soekanto (2009: 62) adaptasi sosial dilakukan dengan cara berinteraksi, karena interaksi sosial adalah hubungan sosial yang dinamis menyangkut hubungan antar individu, antar kelompok, maupun antara individu dengan kelompok. Ciri manusia tersebut menggambarkan betapa berartinya interaksi sosial dalam kehidupan manusia. Merton mengatakan bahwa ada pengaruh dari lingkungan (tekanan struktural) yang kemudian menyebabkan individu menggunakan bentuk adaptasi tertentu ataupun berganti bentuk adaptasi. Robert $\mathrm{K}$ Merton dalam (Siahaan, 2009) menyatakan bahwa ada lima tipe pola adaptasi individu terhadap situasi tertentu. Empat diantaranya merupakan perilaku menyimpang, yaitu:

a) Konformitas, perilaku mengikuti tujuan dan cara yang ditentukan masyarakat untuk mencapai tujuan yang diharapkannya.

b) Inovasi, perilaku mengikuti tujuan yang ditentukan oleh masyarakat tetapi memakai cara yang dilarang oleh masyarakat.

c) Ritualisme, melaksanakan ritual-ritual budaya tapi maknanya telah hilang.

d) Pengunduran atau pengasingan diri, meninggalkan cara hidup yang buruk, baik dengan cara konvensional maupun pencapaiannya yang konvensional.

e) Pemberontakan, penarikan diri dari tujuan konvensional yang disertai dengan upaya melambangkan tujuan atau cara baru.

B. Penyandang Disabilitas

1. Pengertian Disabilitas

Menurut Undang-Undang Nomor 8 tahun 2016 penyandang disabilitas adalah setiap orang yang mengalami keterbatasan fisik, intelektual, mental dan sensorik dalam jangka waktu yang lama dalam berinteraksi dengan lingkungan dapat mengalami hambatan dan kesulitan untuk berpastisipasi secara penuh dengan warga Negara lainnya berdasarkan kesamaan hak.

2. Jenis-jenis dan karakteristik penyandang disabilitas

Penyandang disabilitas merupakan istilah untuk merujuk kepada mereka yang memiliki kelainan fisik atau non-fisik. Undangundang nomor 8 tahun 2016 membagi ragam disabilitas, sebagai berikut:

a) Penyandang Disabilitas Fisik

Terganggunya fungsi gerak, antara lain amputasi, lumpuh layuh atau kaku, paraplegia, celebral palsy (CP), akibat stroke, akibat kusta, dan orang kecil. 
b) Penyandang Disabilitas Intelektual

Terganggunya fungsi pikir karena tingkat kecerdasan di bawah rata-rata, antara lain lambat belajar, disabilitas grahita dan down syndrom.

c) Penyandang Disabilitas Mental

Terganggunya fungsi pikir, emosi, dan perilaku, antara lain: psikososial dan disabilitas perkembangan yang berpengaruh pada kemampuan interaksi sosial.

d) Penyandang Disabilitas Sensorik

Terganggunya salah satu fungsi dari panca indera, antara lain disabilitas netra, disabilitas rungu, dan disabilitas wicara.

Dalam penelitian ini, peneliti memfokuskan pada disabilitas sensorik, yaitu disabilitas netra atau tunanetra. Menurut etimologi tunanetra berasal dari kata tuna berarti rusak dan kata netra berarti mata, dengan demikian tunanetra berarti rusak penglihatan, dan seseorang yang mengalami kerusakan penglihatannya disebut dengan tunanetra. Sedangkan orang yang buta adalah seseorang yang mengalami kerusakan pada penglihatannya Tunanetra dapat dikelompokkan menjadi dua macam (Somantri, 2006: 66), yakni:

a) Buta Total (totally blind), artinya individu yang mengalami totally blind sama sekali tidak mampu menerima rangsang cahaya dari luar (visusnya $=0$ )

b) Kemampuan melihat mata rendah (low vision), artinya individu yang mengalami low vision masih mampu menerima rangsang cahaya dari luar, tetapi ketajamannya lebih dari $6 / 21$.

C. Lingkungan Masyarakat

Menurut kamus besar bahasa Indonesia, kata lingkungan berarti daerah (kawasan dan sebagainya) yang termasuk didalamnya, semua yang mempengaruhi pertumbuhan manusia. Sedangkan menurut Sudiyono (2009: 298) lingkungan adalah semua kondisi dalam dunia ini yang dengan cara-cara tertentu dapat mempengaruhi tingkah laku manusia, pertumbuhan, dan perkembangannya. Hubungan antara manusia dan lingkungan merupakan dua hal yang tidak dapat dipisahkan. Abdul Syani (2015: 30) mendefinisikan masyarakat berasal dari kata musyarak (arab), yang artinya bersama-sama, kemudian berubah menjadi masyarakat, yang memiliki arti berkumpul bersama, hidup bersama dengan saling berhubungan dan saling mempengaruhi, selanjutnya mendapatkan kesepakatan menjadi masyarakat dengan istilah ilmiahnya saling berinteraksi.

D. Tinjauan Sosiologi Mengenai Adaptasi

$$
\text { Keberadaan manusia dengan }
$$

lingkungannya tidak terlepas dari proses adaptasi. Adaptasi yang dilakukan merupakan proses yang membentuk diri individu itu sendiri dalam memenuhi berbagai kebutuhan yang ingin diraih. Abraham Maslow mengungkapkan teori motivasi yang dikenal dengan hierarki kebutuhan (hierarchy of needs). Kebutuhankebutuhan tersebut ialah kebutuhan fisiologis, kebutuhan akan rasa aman, kebutuhan akan rasa memiliki-dimiliki, dan akan kasih sayang, kebutuhan akan penghargaan, dan kebutuhan akan aktualisasi diri (Goble, 1992).

Dalam teori hierarki kebutuhan ini maslow menggambarkan kebutuhan manusia ibarat piramida dan memisahkan lima kebutuhan ke dalam urutan-urutan yang lebih tinggi dan lebih rendah:

1. Kebutuhan fisiologis (physiological needs), pada unsur ini umumnya kebutuhan fisiologis bersifat neostatik (usaha menjaga keseimbangan unsur-unsur fisik).

2. Kebutuhan rasa aman (safety needs), setelah kebutuhan fisiologis terpenuhi, maka akan muncul kebutuhan akan keamanan, atau kebutuhan akan kepastian.

3. Kebutuhan akan rasa memiliki-dimiliki dan kasih sayang (social needs), setelah kebutuhan fisiologikal dan keamanan telah terpenuhi, maka perhatian sang individu beralih pada keinginan untuk mendapatkan kawan, cinta, dan perasaan diterima.

4. Kebutuhan akan penghargaan (self esteem needs), maslow mengemukakan bahwa setiap orang memiliki dua kategori akan penghargaan: yakni, harga diri dan penghargaan dari orang lain.

5. Kebutuhan akan aktualisasi diri (self actualization), setelah kebutuhan dasar manusia telah terpenuhi, yang terakhir ialah kebutuhan aktualisasi diri, kebutuhan menjadi sesuatu yang orang itu mampu untuk mewujudkannya secara maksimal seluruh bakat maupun kemampuan potensinya (Friedman, 2006).

\section{METODE}

Penelitian ini menggunakan metode penelitian kualitatif dengan tipe deskriptif. 
Menurut Sugiyono (2009:1) penelitian kualitatif adalah metode penelitian yang digunakan untuk meneliti pada kondisi obyek yang ilmiah, (sebagai lawannya adalah eksperimen) dimana peneliti adalah sebagai instrumen kunci, tekhnik pengumpulan data bersifat induktif, dan hasil penelitian kualitatif lebih menekankan makna dari pada generalisasi.

Adapun lokasi dalam penelitian ini di Kota Makassar, yaitu anggota organisasi pertuni (Persatuan Tunanetra Indonesia), pertuni merupakan salah satu persatuan disabilitas yang ada di Kota Makassar yang beranggotakan orang-orang disabilitas netra.

Sasaran penelitian atau yang menjadi informan dalam penelitian ini menggunakan cara purposive sampling atau pengambilan data yaitu dengan menentukan kriteria informan. Adapun kriteria dalam pemilihan informan adalah:

1. Penyandang disabilitas netra.

2. Usia 17- 46 tahun

3. Pelajar maupun yang sedang bekerja.

Instrumen utama dalam penelitian ini yaitu peneliti itu sendiri. Sebagai instrumen utama, maka dimulailah dari perencanaan, kemudianpengumpulan data. Data yang telah terkumpul kemudian dianalisis. Penulisan laporan penelitian ini dilakukan oleh peneliti sendiri. Sedangkan dalam mendukung tercapainya hasil penelitian digunakan alat bantu berupa pedoman wawancara, dokumentasi ( perekam dan camera), dan pencatatan hasil penelitian.

Dalam penelitian ini, peneliti menggunakan beberapa teknik pengumpulan data yakni pengamatan (observasi), wawancara (interview), dan dokumentasi.

Adapun teknik penelitian yang digunakan untuk menganalisis data di antaranya: reduksi data, penyajian data dan penarikan kesimpulan.

Sedangkan untuk pemeriksaan keabsahan data peneliti melakukan perpanjangan pengamatan, meningkatkan ketekunan, dan triangulasi.

\section{HASIL DAN PEMBAHASAN}

Setelah dilaksanakan penelitian kurang lebih satu bulan di Kota Makassar, maka dapat diuraikan temuan data lapangan terkait Adaptasi Penyandang Disabilitas di Lingkungan Masyarakat (Studi Kasus Penyandang Disabilitas Netra Pertuni Kota Makassar). Data lapangan diperoleh berdasarkan hasil observasi dan wawancara terhadap informan penelitian. Berikut ini diuraikan temuan hasil wawancara terhadap informan yang memberikan informasi mendalam tentang Adaptasi Penyandang Disabilitas di Lingkungan Masyarakat.

\section{Proses Sosialisasi Yang Dialami Disabilitas Netra Pertuni Di Lingkungan Masyarakat.}

Berdasarkan hasil observasi dan wawancara terhadap seluruh informan diketahui beberapa indikator yang menggambarkan penyebab disabilitas pada diri informan. Dari hasil wawancara, informan mengemukakan tentang penyebab disabilitas netra yang mereka alami, ada dua hal yakni karena disebabkan oleh penyakit atau virus dan ada pula informan menjadi netra akibat kecelakaan. Memiliki keterbatasan pada penglihatan bukanlah suatu keinginan setiap individu, namun anggapan mereka yang mengalami hal ini merupakan suatu ketetapan dari Sang Maha Kuasa. Adapun proses sosialisasi yang dijalaninya ialah dimulai sejak kecil hingga dewasa karena sosialisasi merupakan pembelajaran yang dilakukan secara terus- menerus agar dapat melakukan sesuatu yang harus dilakukan dan tidak boleh dilakukan.

Dalam sosialisasi penyandang disabilitas netra tentunya dilakukan secara bertahap agar dapat mempraktekkan hasil sosialisasi yang telah diberikan. Seperti halnya sosialisasi tentang aktivitas sehari-hari ataupun mengenai kemandirian yang diajarkan dan dilatih secara terus-menerus. Sosialisasi yang dialami disabilitas netra tentu berbeda-beda, mereka punya cara tersendiri untuk mengekspresikan dirinya.

\section{Bentuk-Bentuk Adaptasi Penyandang Disabilitas Netra Di Lingkungan Masyarakat.}

Adaptasi merupakan sebuah proses panjang yang dilalui individu disabilitas untuk dapat diterima di tengah-tengah masyarakat. Seseorang tidak akan dapat menyesuaikan diri dengan lingkungannya jika tidak melakukan proses-proses sosialisasi. Dari adanya sosialisasi yang dijalani mulai dari keluarga, sekolah, bahkan organisasi para penyandang disabilitas netra mendapat ilmu yang bermanfaat bagi kehidupannya di lingkungan. karena dalam sosialisasi itu sendiri diajarkan berbagai macam hal secara mental maupun fisik agar para peyandang disabilitas netra dapat mengekspresikan diri dan kemampuannya serta mampu beradaptasi di lingkungannya. Secara 
lebih jelas, bentuk-bentuk adaptasi penyandang disabilitas dapat diklasifikasikan sebagai berikut:

a) Konformitas

Dari keseluruhan data hasil observasi dan wawancara mendalam terhadap beberapa informan, Diketahui bentuk-bentuk adaptasi yang menggambarkan penyandang disabilitas netra di lingkungan masyarakat. Hal ini berdasarkan pengalaman serta aktivitas penyandang disabilitas netra di lingkungan masyarakat. Banyak sekali anggapan salah dari masyarakat terkait kondisi yang dialami informan. Ada stigma miring yang berkembang di masyarakat mengenai kondisi informan, sebagian masyarakat masih melihat penyandang disabilitas sebagai orang-orang yang patut dikasihani. Seluruh informan juga dalam penuturannya mengatakan tidak mampu berbuat apa-apa dengan stigma yang ada di masyarakat.

Begitu halnya dengan cerita penyandang disabilitas netra yang memberanikan diri untuk dapat berinteraksi dan beraktivitas seperti orang lain pada umumnya tanpa harus merasa minder karena kondisi fisik yang berbeda. Pilihan mereka membuat siasat dalam beradaptasi di lingkungan ia berada tidak terlepas dari stereotype masyarakat yang menganggap mereka yang mengalami disabilitas memiliki kemampuan terbatas atau tidak berguna di masyarakat. Hasil wawancara dengan seluruh informan menunjukkan, bahwa tidak ada alasan kekurangan fisik untuk tidak berbaur dengan lingkungan setempat.

Memiliki kemampuan yang berbeda (different ability) bukan halangan menjadi malu tampil dan mengambil peran di lingkungan sosial. Harus diakui bahwa keterbatasan yang dimiliki oleh penyandang disabilitas netra sangat mempengaruhi eksistensi mereka di tengah masyarakat. Semangat juang para penyandang disabilitas netra dalam menghapuskan hambatan internal akan lebih mudah dihadapi ketika mendapat dukungan dari keluarga dan masyarakat sekitarnya. Termasuk dalam memberikan pemahaman positif kepada masyarakat bahwa penyandang disabilitas semestinya diperlakukan tanpa diskriminasi dan marjinalisasi.

b) Pengunduran atau Pengasingan Diri

Umumnya pengasingan diri terjadi pada diri penyandang disabilitas netra karena ketidakmampuan menerima keadaan dengan tuntutan sosial. Namun, hal ini tidak berlangsung lama, proses perubahan ini bertujuan untuk menyesuaikan dengan situasi yang berubah.

\section{Faktor-Faktor Yang Mempengaruhi Adaptasi Penyandang Disabilitas Netra Di Lingkungan Masyarakat.}

Faktor-faktor pendorong serta penghambat menjadi cerita yang tidak dapat terpisahkan dalam proses panjang adaptasi yang dilalui penyandang disabilitas netra. Hal tersebut dapat dilihat sebagai berikut:

a) Faktor Pendorong

1. Kebutuhan fisiologis

Tidak dapat dipungkiri faktor fisiologis merupakan kebutuhan dasar setiap manusia termasak penyandang disabilitas netra. Kebutuhan fisiologis terkait kebutuhan seharihari. Dengan memiliki pekerjaan serta menerima pendapatan sendiri mampu menaikkan derajat sosial penyandang disabilitas dan bukan hanya sebagai ajang mematahkan stereotype di tengah masyarakat bahwa penyandang disabilitas tidak mampu mengembangkan diri, lebih lanjut juga agar penyandang disabilitas mampu secara mandiri mencukupi kebutuhan hidupnya bahkan keluarganya.

2. Kebutuhan rasa aman (Safety Needs)

Dengan beraktivitas baik di lingkungan kerja ataupun di lingkungan sekolah, timbul rasa aman dalam diri penyandang disabilitas. Rasa aman ini tidak lahir dari ruang hampa melainkan karena adanya peran yang dimainkan penyandang disabilitas netra yang membuatnya merasa memiliki kesempatan untuk mengembangkan dirinya. Dapat disimpulkan bahwa pentingnya mengetahui kondisi suatu lingkungan berhubungan dengan timbulnya perasaan aman dalam diri penyandang disabilitas netra. Menghindari konflik juga salah satu cara untuk mendapatkan rasa aman.

3. Kebutuhan akan rasa memiliki-dimiliki dan kasih sayang (Social Needs)

Dalam perjalanan adaptasinya, tentu ada goals yang hendak dicapai oleh penyandang disabilitas netra salah satunya dengan terpenuhinya social needs. Dengan kata lain, penyandang disabilitas merasa butuh untuk dipandang sederajat dengan mereka tanpa disabilitas. Selain menumbuhkan rasa aman, dihargai, dan diakui keberadaannya. Hal ini mampu menaikkan semangat serta kepercayaan diri penyandang disabilitas netra bahwa diri mereka mampu dan memiliki kesamaan kemampuan dengan orang-orang yang bukan disabilitas. 
4. Kebutuhan akan penghargaan (Esteem Needs)

Ketika penyandang disabilitas netra mampu membuktikan bahwa kemampuannya sama dengan orang-orang non disabilitas, maka akan timbul dalam dirinya rasa kepercayaan diri. Namun perasaan ini juga harus sejalan dengan penerimaan masyarakat berupa penghargaan. Rasa percaya diri harus dibarengi dengan penerimaan dalam bentuk penghargaan oleh masyarakat dalam hal ini untuk memenuhi esteem needs penyandang disabilitas netra.

5. Aktualisasi diri

Adanya kebutuhan aktualisasi diri inilah yang cukup besar menuntut penyandang disabilitas netra untuk menggali dan mengembangkan potensi yang mereka miliki. Oleh karena itu, informan disabilitas netra baik itu yang sedang menempuh pendidikan umum maupun yang sedang bekerja, sesuai makna yang dialami yaitu sebagai usaha untuk menunjukkan eksistensi diri sebagai penyandang disabilitas. Dan makna tersebut akan muncul dalam proses adaptasi. Dengan pemaknaan bahwa menggeluti suatu pekerjaan juga merupakan suatu bentuk eksistensi diri yaitu kebutuhan akan penghargaan dimana kebutuhan tersebut untuk memperoleh kehormatan, pujian, dan pengakuan.

b) Faktor penghambat

Sudah bukan rahasia bahwa masyarakat sering kali mengkonotasikan hal-hal yang diluar umum sebagai sesuatu yang luar biasa. Begitu pula meyoal keadaan fisik manusia. Sejatinya tidak ada individu yang memiliki keinginan untuk dilahirkan atau dalam perjalanan hidupnya menjadi peyandang disabilitas netra. Namun stigma masih menjadi suatu bahan perbincangan dalam masyarakat. Sebelum mengenal istilah disabilitas masyarakat sering memberi sebutan "cacat" untuk mengelompokkan orang-orang dengan keadaan fisik yang berbeda. Masih adanya stigma di tengah-tengah masyarakat, terkadang kondisi ini melemahkan kemampuan yang dimiliki penyandang disabilitas netra. Timbulnya perasaan takut datang dari luar diri mereka. Mereka yang sudah mampu menerimma diri dan mengatasi hambatan dalam diri masih harus berhadapan dengan anggapan yang datang dari luar.

\section{Pembahasan}

\section{Proses Sosialisasi Yang Dialami Disabilitas Netra Pertuni Di Lingkungan Masyarakat}

Suatu proses sosialisasi yang didapatkan tentunya memberi nilai-nilai pada penyandang disabilitas netra bagi kehidupan sehari-harinya. Dengan proses panjang sosialisasi, penyandang disabilitas netra dapat menjadi lebih dewasa ketika menghadapi segala tantangan dalam hidupnya. Penyandang disabilitas netra mampu melakukan suatu hal atau menghadapi persoalan, dan kedisplinan yang selalu diterapkan membuat penyandang disabilitas netra dapat mengelola informasi dengan baik serta ia dapat lebih dihargai dalam lingkungan masyarakat.

Sosialisasi tidak hanya didapatkan dalam lingkungan keluarga, melainkan diluar daripada lingkungan keluarga juga seperti halnya sekolah, organisasi, tempat kerja, hingga lingkungan masyarakat. Elly dan Usman (2011: 156) mengungkapkan bahwa sosialisasi tidak hanya sekedar proses menyebarluaskan informasi dalam rangka memengaruhi seseorang atau publik agar berbuat sesuatu, seperti mengajar, mengumumkan, memberikan doktrinasi saja akan tetapi di dalam proses tersebut seseorang juga diberi kesempatan untuk membangun dirinya, sebab sosialisasi tidak hanya sekedar memberi tahu tentang suatu hal, tetapi ia juga merupakan proses pendewasaan dan pematangan kepribadian seorang individu.

\section{Bentuk-Bentuk Adaptasi Penyandang Disabilitas Netra Di Lingkungan Masyarakat}

Penyandang disabilitas merupakan sebagian dari kelompok masyarakat yang telah di konstruk oleh wacana sosial mengenai kondisi tubuh. Wacana ini dalam prosesnya menimbulkan ketimpangan dan cenderung meminggirkan mereka yang disabilitas. Hal ini terkait dengan stereotype yang berkembang dalam masyarakat pada orang lain.

\section{a. Konformitas}

Keberadaan mereka sempat tidak diterima oleh lingkungannya, tetapi adanya bentuk-bentuk adaptasi yang mereka jalankan. Mereka pada akhirnya yang harus menyesuaikan diri dengan orang-orang non disabilitas. Penyesuaian diri berlangsung secara terusmenerus untuk memenuhi kebutuhan diri sendiri dengan tuntutan lingkungan, termasuk tuntutan orang lain secara kelompok maupun masyarakat. Hal ini sesuai dengan Calhoun dan Acocella (1990: 13) menyatakan bahwa penyesuaian diri adalah interaksi secara terus-menerus antara individu dengan orang lain dan dengan lingkungan sekitar tempat individu itu berada. 


\section{b. Pengasingan diri}

Pengasingan diri ini dapat dikatakan ketidakmampuan dalam berinteraksi dengan masyarakat pasca mengalami kondisi yang diluar dugaannya. Mereka yang mengalami kesulitan dalam adaptasinya kemudian menyalurkan ketegangan tersebut menjadi suatu bentuk pengasingan diri. Mengasingkan diri terjadi apabila penyandang disabilitas tidak mampu melalui hambatan-hambatan baik yang sifatnya internal maupun eksternal.

\section{Faktor-Faktor Yang Mempengaruhi Adaptasi Penyandang Disabilitas Netra}

\section{a) Faktor Pendorong}

Faktor pendorong ini dilihat dengan kacamata Abraham Maslow tentang hierarki kebutuhan. Bahwa tidak dapat dipisahkan antara keinginan beradaptasi dengan pemenuhan kebutuhan. Teori hierarki kebutuhan maslow membentuk suatu tingkatan untuk mengklasifikasikan kebutuhan satu dan kebutuhan yang lain. Artinya, ketika telah memenuhi kebutuhan pada level paling bawah (kebutuhan fisiologis) akan terus naik ke level kebutuhan lainnya hingga sampai pada puncak kebutuhan aktualisasi diri. Pada pemenuhan kebutuhan fisiologis, penyandang disabilitas netra mengharapkan dengan bekerja dapat memperoleh gaji lalu menyalurkan pendapatan tersebut untuk memenuhi kebutuhannya seperti makan, minum, membeli pakaian dan sebagainya. Hal ini sebagai motivasi untuk terus menyesuaikan diri dengan lingkungan tempat kerja agar dapat memenuhi kebutuhan tersebut.

Di antara hierarki kebutuhan Maslow, social needs memiliki korelasi dengan proses adaptasi penyandang disabilitas netra. Bahwa penekanan alasan mereka dengan disabilitas melakukan adaptasi erat kaitannya dengan penerimaan masyarakat. Hingga pada puncak hierarki akan muncul kebutuhan akan aktualisasi diri. Aktualisasi diri bukan berarti mencapai titik kesempurnaan, namun bagi diri penyandang disabilitas netra artinya telah mampu secara mandiri mengembangkan potensi yang dimiliki. Maslow dalam (Goble, 1992: 72) melukiskan kebutuhan ini sebagai "hasrat untuk makin menjadi diri sepenuh kemampuannya sendiri, menjadi apa saja menurut kemampuannya.

Pentingnya penyandang disabilitas sekurang-kurangnya merasa berguna di lingkungan sosialnya dapat mendorong penyandang disabilitas netra untuk berprestasi. Karena kemampuan penyandang disabilitas netra tidak kalah dengan masyarakat normal, tetapi tidak banyak yang menjadikan mereka prioritas. Tidak dapat dipungkiri bahwa penyandang disabilitas netra juga memiliki semangat aktualisasi diri lebih tinggi dibanding individu tanpa disabilitas.

b) Faktor Penghambat

Selain faktor pendorong juga terdapat faktor penghambat yang mempengaruhi adaptasi penyandang disabilitas di lingkungannya. faktor penghambat disebabkan oleh stigma yang terlanjur hidup di tengah-tengah masyarakat. Stigma ini kemudian diperburuk dengan tindakan-tindakan seperti pengucilan, diskriminatif, serta peminggiran (marjinalisasi) karena dianggap penyandang disabilitas adalah kelompok yang tidak berdaya.

Menurut Thohari (2014: 34) umumnya masyarakat masih melihat penyandang disabilitas sebagai "ketidaknormalan", dengan standar kenormalan yang direproduksi terusmenerus dalam masyarakat yaitu tubuh sebagaimana tubuh orang banyak. Pernyataan ini menunjukkan bahwa masyarakat telah memberikan atribut yang dapat mengganggu identitas penyandang disabilitas. Seperti yang dikemukakan oleh Goffman dalam (Ritzer, 2004) bahwa stigma yang muncul di masyarakat aka mengganggu dan menghalangi partisipasi penuh mereka yang terstigma dalam masyarakat.

Fakta bahwa dalam perjalanannya penyandang disabilitas juga mendapati hambatan berupa tidak memiliki peluang, akses dalam menempuh pendidikan umum, dan bahkan kesempatan kerja lebih banyak dibandingkan dengan orang tanpa disabilitas. Informan menyebutkan sulitnya mengakses pendidikan umum dan pekerjaan karena kondisi fisik. Dalam hal ini masalah fisik yang dialami disabilitas membuat mereka ditolak karena terlihat berbeda. Namun, hal ini tidak mematahkan semangat disabilitas, mereka tetap berjuang dan mampu membuktikan dan memperlihatkan kemampuannya.

\section{SIMPULAN DAN SARAN}

Kesimpulan penelitian adalah:

Penyandang disabilitas netra dalam proses sosialisasi yang dialami terdapat sikap, nilai, norma, dan perilaku esensial yang dapat diterapkan di kehidupannya agar mampu untuk beradaptasi dan berpartisipasi secara efektif dalam masyarakat; (2) Bentuk adaptasi penyandang disabilitas netra melahirkan (a) 
Fadhilah, et all. Adaptasi Penyandang Disabilitas di Lingkungan...

konformitas yang merupakan usaha penyesuaian diri peyandang disabilitas netra dengan mengikuti cara yang berlaku dalam masyarakat, sera (b) pengasingan diri sebagai alternative di awal-awal penyandang disabilitas netra tidak mampu menerima keadaan diri (isolasi diri); (3) Adapun faktor-faktor yang mempengaruhi adaptasi penyandang disabilitas yaitu faktor pendorong adanya kebutuhan (a) fisiologis seperti makan, minum, dan berpakaian, (b) rasa aman yaitu terhindar dari tindakan bullying, (c) rasa kasih sayang yang muncul dari lingkungan sekitar, (d) kebutuhan akan penghargaan seperti berprestasi, dihargai, dan diakui,serta (e) aktualisasi diri dimana penyandang disabilitas netra mampu mengembangkan potensi yang dimiliki. Adapun faktor penghambat yaitu stigma, dimana masyarakat dalam hal ini masih memberi stigma negatif terhadap keberadaan penyandang disabilitas netra, selain itu penyandang disabilitas juga mendapati hambatan berupa sangat kurangnya peluang, akses dalam menempuh pendidikan umum, dan bahkan kesempatan kerja.

Saran penelitian adalah: (1) Bagi Penyandang Disabilitas, perbedaan yang terjadi seharusnya dilihat sebagai perbedaan yang horizontal bukan secara vertical, oleh karenanya individu penyandang disabilitas netra harus mampu memaksimalkan kemampuan serta potensi diri untuk mematahkan stigma-stigma miring dalam masyarakat terhadap keberadaannya; (2) Bagi Masyarakat, perlunya mengenali penyandang disabilitas melalui pemahaman dasar bahwa mereka berkemampuan berbeda (different ability) bukan tidak berkemampuan (disabled) serta menciptakan masyarakat inklusif yaitu dimana penyandang disabilitas mendapatkan pegakuan serta mendapatkan peluang untuk berpartisipasi langsung dalam lingkungan sosial. atau dengan kata lain, masyarakat inklusif adalah masyarakat tanpa diskriminasi (atas dasar disabilitas); (3) Bagi Pemerintah, sebagai stakeholders diharapkan mampu membuat regulasi peraturan perundang-undangan yang menguatkan keberadaan penyandang disabilitas dalam posisi hak dan kewajiban yang sama dengan warga Negara lainnya.

\section{DAFTAR RUJUKAN}

Acocella, J. R. 2011. Psikologi Tentang Penyesuaian dan Hubungan Kemanusiaan. Semarang: IKIP Press.
Agustiani, H. 2006. Psikologi Perkembangan: Pendekatan Ekologi Kaitannya dengan Konsep Diri dan Penyesuaian Diri pada Remaja. Bandung: PT. Refika Aditama.

Damsar. 2011. Pengantar Sosiologi Pendidikan. Jakarta: Kencana.

Desmita. 2009. Psikologi Perkembangan. Bandung: Remaja Rosdakarya.

Goble, F. 1992. Psikologi Humanistik Abraham Maslow. Yogyakarta: Kanisius.

Ritzer, G. 2004. Teori Sosiologi Modern. Jakarta: Prenada Media.

Setiadi, E. M. 2011. Pengantar Sosiologi: Pemahaman Fakta dan Gejala Permasalahan Sosial: Teori. aplikasi dan pemecahannya. Jakarta: Kencana Prenadamedia Group.

Siahaan, J. 2009. Perilaku menyimpang: Pendekatan Sosiologi. Jakarta: Indeks.

Soekanto, S. 2009. Sosiologi Suatu Pengantar. Jakarta: Rajawali Pers.

Soemantri, S. 2006. Psikologi Luar Biasa. Bandung: PT. Referika Aditama.

Sudiyono. 2009. Ilmi Pendidikan Islam. Jakarta: Rineka Cipta.

Sugiyono. 2009. Metode Penelitian Kuantitatif Kualitatif dan $R \& D$. Bandung: PT. Alfabeta.

Syani, A. 2015. Sosiologi Skematika Teori dan Terapan. Jakarta: Bumi Aksara.

Thohari, S. 2014. pandangan Disabilitas dan Aksebilitas Fasilitas Publik bagi Penyandang Disabilitas di Kota Malang. IJDS (Indonesia journal of Disability studies), Vol. 1, No. 1. 